\title{
AGRICULTURAL APTITUDE OF LANDS AND CONFLICTING USES IN PERMANENT PRESERVATION AREAS OF RIBEIRÃO JACOBINA BASIN IN CÁCERES/ MATO GROSSO STATE, BRAZIL
}

\author{
Larissa Espinosa de FREITAS ${ }^{1}$ \\ Sandra Mara Alves da Silva NEVES² \\ Maria Cândida Moitinho NUNES 3 \\ Milson Evaldo SERAFIM4 \\ Diego Galvão de PAULA
}

\begin{abstract}
The expansion of agricultural activities in areas of high environmental sensitivity results in negative effects on the environment. The objective of this work is to evaluate by geo-technologies the agricultural aptitude of lands and the conflicts of use in Permanent Preservation Areas (PPAs) along rivers and springs in the Ribeirão Jacobina Basin in Cáceres municipality / Mato Grosso State. Using a Geographic Information System, it was possible to intersect those maps referring to soil classes, relief, agricultural aptitude, land use/land cover. The Brazilian Forest Code and its determinations were used as basis for the evaluation of land use conflicts in PPAs. It was verified that $67.47 \%$ of the territory of the basin is suitable for livestock/agricultural activities. There are conflicts of land use in areas with occurrence of Humic Cambisols, Haplic Luvisols and Litholic Neosols in hilly relief with predominance of livestock. Land use/land cover within the APPs, demonstrated that 1,802 hectares of the basin correspond to areas of water resources protection, and from this total, 459 hectares are being used for livestock activities and 23 hectares for reforestation, and there are conflicts between current use and current legislation. It was concluded that work is needed to recover PPAs in the basin, aiming at maintaining water quality and availability.
\end{abstract}

Key words: Remote Sensing. Land use/Land cover. Environmental conservation. Pantanal. Landscape.

\footnotetext{
1 Master in Environment and Agriculture Production Systems at the University of Mato Grosso State UNEMAT / Campus Tangara da Serra. Rod. MT 358 Km 07 CP 287 Garden Airport Tangara da Serra, Mato Grosso, Brazil CEP: 78300-000. E-mail: larissa-efreitas@hotmail.com

2 Associate professor of geography department. University of the State of Mato Grosso - UNEMAT / Campus Cáceres. Geotechnology Laboratory. Av. Santos Dumont, s/n. Santo Dumont. CEP: 78200-000 Cáceres / MT, Brazil.E-mail: ssneves@unemat.br.

${ }^{3}$ Associate professor of agronomy department. Federal University of Pelotas (UFPEL) Faculty of Agronomy Eliseu Maciel / FAEM. Department soils. Campus s/n, CP 354, CEP: 96010-900, Pelotas / RS, Brazil.Universidade Federal de Pelotas - UFPEL. E-mail: nunes.candida@gmail.com

${ }^{4}$ Instituto Federal Education, Science and Technology - IFEST/ Campus Cáceres Soil Laboratory. Av. Dos Ramires, s / n. Setor Industrial. CEP: 78200-000 Cáceres / MT, Brazil. E-mail: milson.serafim@cas.ifmt.edu.br

${ }^{5}$ Associate professor of department of law. University of the State of Mato Grosso - UNEMAT / Campus Cáceres. Av. São João, s/n, Cavalhada. CEP: 78200-000 Cáceres / MT, Brazil. E-mail: diego.galvao@unemat.br
} 


\section{Resumo}

\section{Aptidão agrícola das terras e usos conflitantes nas áreas de preservação permanente da Bacia Ribeirão Jacobina em Cáceres/MT, Brasil}

A expansão das atividades agrícolas em áreas de alta sensibilidade ambiental resulta em efeitos negativos para todo ambiente. O objetivo deste trabalho é avaliar, por meio das geotecnologias, a aptidão agrícola das terras e os conflitos de uso em Áreas de Preservação Permanentes (APPs) de rios e nascentes na Bacia Ribeirão Jacobina em Cáceres/MT. O Sistema de Informações Geográficas possibilitou a intersecção dos mapas referentes às classes de solo, relevo, aptidão agrícola e uso e cobertura da terra. Para avaliação dos conflitos de uso em (APPs) foi utilizado como base o Código Florestal brasileiro e suas determinações. Verificou-se que $67,47 \%$ da extensão territorial da bacia é apta para atividades agropecuárias. Há conflitos de uso da terra em áreas com ocorrência de Cambissolos Húmicos, Luvissolos Háplicos e Neossolos Litólicos em relevo acidentado com predominância da pecuária. O uso e cobertura das APPs demonstraram que 1.802 hectares da bacia correspondem às áreas de proteção de recursos hídricos, e desse total, 459 hectares estão sendo destinados às atividades pecuárias e 23 hectares para reflorestamento, havendo conflitos entre o uso atual e a legislação vigente. Concluiu-se que são necessários trabalhos de recuperação das APPs na bacia, visando a manutenção da qualidade e disponibilidade da água.

Palavras-chave: Sensoriamento Remoto. Uso e cobertura da terra. Conservação ambiental. Pantanal. Paisagem.

\section{INTRODUÇÃO}

The expansion of agricultural activities in the SW planning region of Mato Grosso State (MT) reflects the need for a rational land use planning to promote the recovery, conservation and sustainable exploitation of the natural elements from the landscape. Pereira e Lombardi Neto (2004) corroborate this issue discussing on the relevance to adopt methodologies which provide more precise and adequate planning and decision making, with a more effective view on the incorporation of the environmental component in the process taking place.

The development of human activities in Mato Grosso State has affected the constituent landscape elements of the hydrographic basins, which are natural hydrological entities allowing the superficial water flow to a specific drainage channel, stream or river at a particular point (CHOPRA et al., 2005). According to Pinto et al. (2005) the characterization of the physical environment from a river basin allows the identification of critical areas for the water maintenance, and it is also a basic condition for successful planning of water conservation.

Several studies contribute to land use planning on watersheds, using the System for Agricultural Aptitude Assessment (SAAT), elaborated by Ramalho Filho and Beek (1995), for the evaluation of land use in Brazil, considering many detailed levels and adaptations. According to Silva et al. (2010), Geo-Technologies and Geographic Information Systems (GIS) are tools which provide promising results to assess the agricultural suitability of land, because they allow the generation, manipulation, analysis and integration of spatial information.

The application of agricultural aptitude analysis in watersheds allows the identification of restrictive constraints, differentiating suitable areas for natural pastures, forestry, areas of ecological interest and underutilized land, since these lands could be 
occupied with high quality pasture and an improved support capacity or with annual cultures with a fast capital return (MARQUES et al., 2012; GOMES et al., 2007).

The need to monitor the conservation status of the vegetation around rivers and springs is supported by the Brazilian Law Nr. 12.651/2012 (BRASIL, 2012), which is the legal basis considered for the definition of Permanent Preservation Areas (PPAs). Its function is to protect the landscape, biodiversity, geological stability, facilitate the genetic flow of fauna and flora, as well as to protect the soil, reducing erosion and compaction processes. However, several studies have shown that the inadequate use of PPAs results in areas with conflicting uses, and there is no adequate protection of water sources (CHAUD et al., 2015, FERRARI et al., 2015, SANTOS et al., 2015).

The conservation of the floodplain within the Upper Paraguay Basin is directly related to the human activities developed on the adjacent Plateau areas. In this context, geo-technologies baes on satellite data can help to identify those areas presenting land use conflicts (PESSOA et al., 2013), as well as at the occupation of environmentally fragile areas, and contributing to the economic development in consonance with environmental conservation.

In this frame, the objective of this study is to evaluate the agricultural aptitude and land use conflicts in PPAs along the tributaries and water sources of Ribeirão Jacobina basin, in the municipality of Cáceres, Mato Grosso State, using geotechnologies.

\section{MATERIAL AND METHODS}

\section{Area under study}

The Ribeirão Jacobina basin, with an extension of 44475 hectares, is located in the municipality of Cáceres, Mato Grosso State (Figure 1). Its main river, the Ribeirão Jacobina, is a tributary of the left margin from the Paraguay River, the largest one from the Upper Paraguay basin (BAP).

Within this basin, the following geomorphologic units occur: Mountainous Province and Cáceres Wetland, one of the sub-units from the so-called Pantanal Matogrossense (SILVA e ABDON, 1998), as well as the biomes Cerrado (Savanna) and Pantanal. Here the wetland environment predominates. The climate in the municipality is hot and humid with a dry winter season (NEVES et al., 2011). 


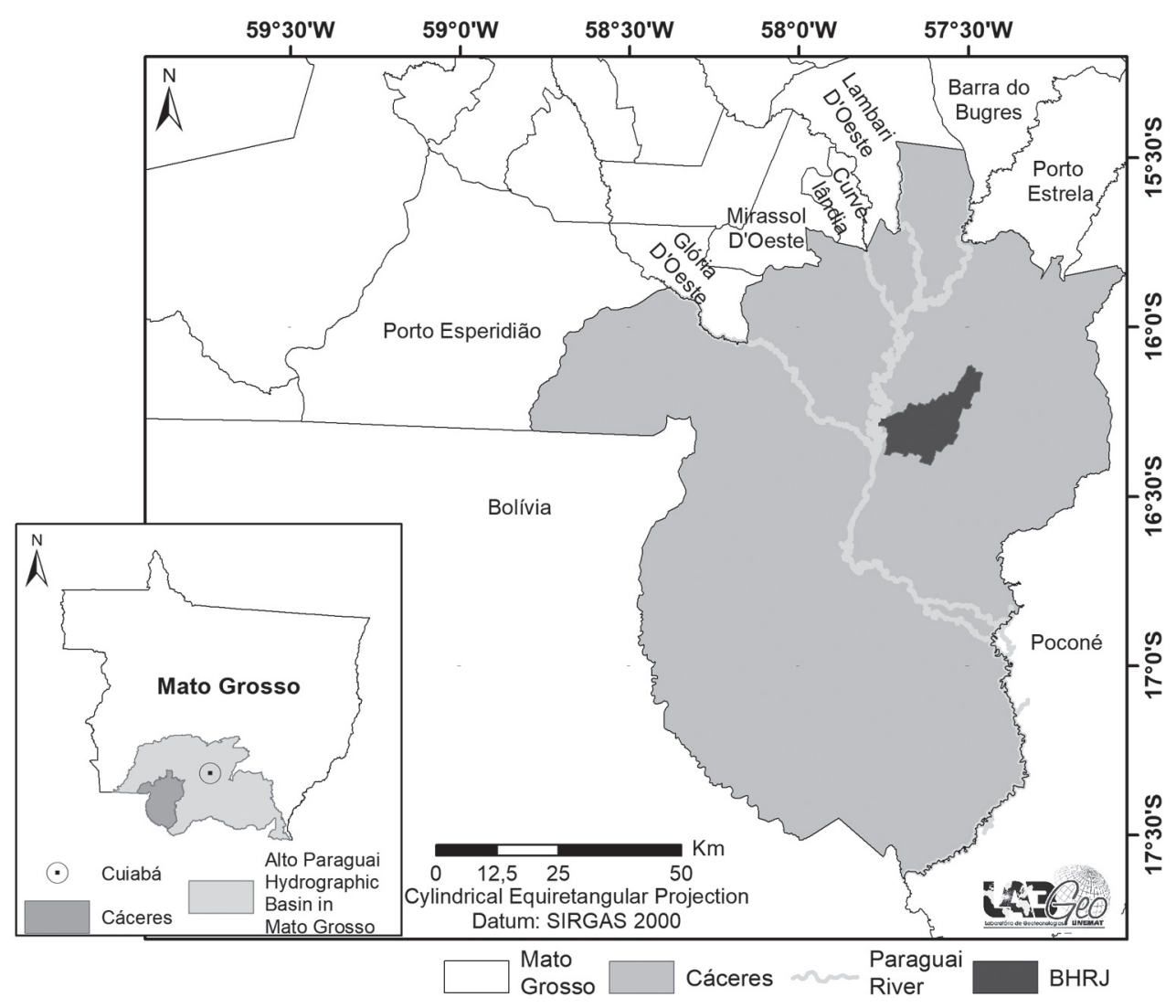

Figure 1 - Ribeirão Jacobina basin within Mato Grosso State, BAP and Cáceres municipality

Source: LabGeo Unemat, 2016.

\section{Methodological procedures}

Initially a survey was made on thematic mapping performed by public institutions (SEPLAN/MT, SEMA/MT, IBGE, MMA, INPE and ANA). Data of interest were compiled, made compatible and organized in a Geographic Databank (GDB) in the ArcGIS 10.5 environment from ESRI (2017).

The Soils map was obtained from Mato Grosso State Secretary for Planning (MATO GROSSO, 2006) and its nomenclature upgraded according to Brasil (2013). The topographic map (LS) was generated from SRTM (Shuttle Radar Topography Mission) scenes of the Digital Elevation Model (DEM), band C, spatial resolution $30 \times 30 \mathrm{~m}$. The images were mosaicked and clipped for the area under study (mask), resulting in the DEM mentioned. Map projection WGS 84 was converted to SIRGAS 2000 UTM, using ArcToolbox of ArcGIS. From the DEM raster file and computer techniques, declivity and slope were generated. These maps were reclassified and combined to generate a 
map of homogeneous ramps, from which values on the average slope and height of these ramps were obtained according to the methodology from Fornelos e Neves (2007).

The relief was classified according to Brasil (2007), where the slope conditions, length of ramps and surficial terrain configuration are qualified. The relief features are defined as follows: slope 0 to $3 \%$ - flat relief; 3.1 to $8 \%$ gentle rolling relief; 8.1 to $20 \%$ rolling relief; 20.1 to $34 \%$ strong rolling relief; 45.1 to $75 \%$ mountainous relief and $>75 \%$ scarped relief.

The evaluation of the agricultural aptitude of lands in the area under study was done based on the System for Agricultural Aptitude Assessment (SAAT) proposed by Ramalho Filho e Beek (1995). Aptitude groups 1, 2 and 3 identify land whose most intensive use is tillage; Group 4 represents land whose type of intensive use is planted pasture; In group 5 are land whose most intensive use is limited to forestry and natural pasture; Group 6 covers areas of land considered unfit for any of the abovementioned agricultural activities, and their occupation is conditioned to the preservation of fauna and flora.

The classes are divided as follows: (a) - restricted aptitude class for management level $A$; a- regular fitness class for management level $A$; $b$ - regular class for management level $B$; (b) - class restricted for management level $B$; c - regular class for management level $C$; $p$ - regular class for pastures planted at management level B; N - good class for natural pasture at management level A; S - good class for forestry at management level $\mathrm{B} ; \mathrm{f}$ - class restricted by agro-environmental conditions (relief and/or soil and/or climate), indicated for the preservation of fauna and flora.

For the elaboration of the land use/land cover map, images of Sentinel 2A satellite, with a resolution of $10 \mathrm{~m}$ from July 2016, obtained on the website of ESA (https://sentinels.copernicus.eu/web/sentinel / Sentinel-data-access) were used. A Geographic Database (BDG) was developed on SPRING software, version 5.2.6 from INPE (CÂMARA et al., 1996), using the UTM system, 21S and SIRGAS 2000 Datum. Following bands $2(0.560 \mu \mathrm{m}), 4(0.665 \mu \mathrm{m})$ and $8(0.842 \mu \mathrm{m})$ were imported and used to perform the mosaic and masking of the area under study. The segmentation method was carried out using the region growth procedure, with both similarity and pixel area at 100. For the definition of land use and land use cover, the technical land use manual was used (BRASIL, 2013).

The map of land use conflicts was elaborated from the combination of Agricultural Aptitude maps Land use/land cover maps, according to Pedron et al. (2016), classifying the areas of this Basin as high, medium and low.

To perform the delimitation of water bodies and springs within the basin, RapidEye satellite images were used, which were delivered by the Ministry for Environment. Using the buffer tool from ArcGIS information on vegetation cover from the surroundings of water bodies and springs were extracted. Permanent Preservation Areas (PPAs) were delimited according to Law No. 12.651/2012 (Brazilian Forest Code): the PPAs must have a minimum radius of $50 \mathrm{~m}$ around the springs and perennial water sources and a minimum width of $30 \mathrm{~m}$ along water courses, at least $10 \mathrm{~m}$ wide (BRASIL, 2012).

During the verification of land use conflict at the PPAs, the above mentioned Law was taken into account, specifically regarding its Article 4, referring to those areas where there was no native vegetation left around rivers and springs, disregarding clearly the legal limits for its preservation. A field survey was done to validate the cartographic product generated, aiming to obtain the ground truth.

A field survey was done in August 2016 to check the ground truth, as well as to evaluate land use conflicts in PPAs of rivers and springs in the area under study. Using 
a GPS the coordinates of places visited were obtained, which were registered with a camera at geo-referenced places.

\section{RESULTS AND DISCUSSION}

The predominant soil type within the basin is Litholic Neosols (Table 1 and Figure 2 ) covering the rolling to strongly rolling relief (Figure 3), which is important for the conservation of the native vegetation to avoid increase of erosion processes. Cutrim e Campos (2010) report the occurrence of Litholic Neosols in sections of Rio Vermelho basin, within the domains of the Pantanal from MT, in Rondonópolis (MT). These authors emphasize the importance of the vegetation in these areas, considering the rock outcrops, small depth of soils and presence of stone covered sections.

\section{Table 1 - Soils within the Ribeirão Jacobina basin in the municipality of Cáceres/MT}

\begin{tabular}{lrr}
\hline Soil classes & Area (ha) & \% \\
\hline Humic Cambisols & 147 & 0.33 \\
Red Yellow & 7,454 & 16.7 \\
Oxisols & 10,902 & 24.5 \\
Red Oxisols & 11,595 & 26.27 \\
Haplic Luvisols & 391 & 0.79 \\
Fluvic Arenosols & 13,986 & 31.41 \\
Litholic & $\mathbf{4 4 , 4 7 5}$ & $\mathbf{1 0 0}$ \\
\hline Trenosols & & \\
\hline
\end{tabular}

The Haplic Luvisols occur under gentle rolling relief (Table 1 and Figures 2, 3) and advocates conservationist practices for soil management, since it is apt for perennial cultures or agro-forestry systems, to keep the conservation of physical, chemical and biological soil qualities. According to Brasil (2013) these qualities include: mineral soils, with textural B horizon with high activity clay, shallow to low depth, highly susceptible to erosion processes, due to the big difference among A and B horizons.

The Red Oxisols are situated in areas with flat to gentle rolling relief (Figures 2 and 3). According to Nunes e Cassol (2008) they present a high aggregate stability, being resistant to the impact of raindrops and to the action of surface flow, contributing to its resistance to environmental impacts. The Oxisols present favorable physical attributes for the agriculture, being little susceptible to erosion processes, contributing to the adequate tillage of annual cultures.

In the area under study there are 5 relief types and among them the gentle rolling one, which covers $32.4 \%$ of the territory and the flat terrain occupying $25.73 \%$. Both relief types are mainly covered by Oxisols. According to Lepsch et al. (2015) those areas with declivity between 0 and $6 \%$ (Flat to Gentle rolling) are destined for the plantation of annual cultures, using simple soil conservation practices. To control erosion processes it is suggested to execute tillage considering the contour lines. 


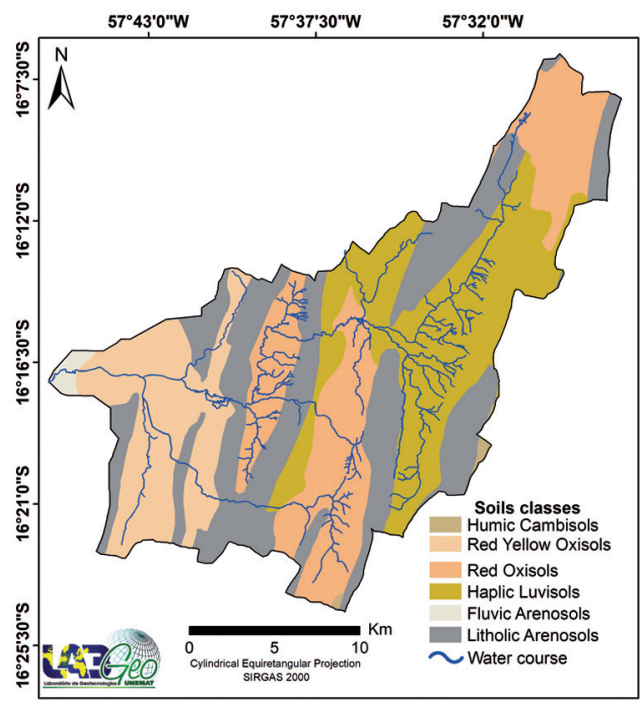

Figure 2 - Soil classes identified in the Ribeirão Jacobina basin Cáceres/MT

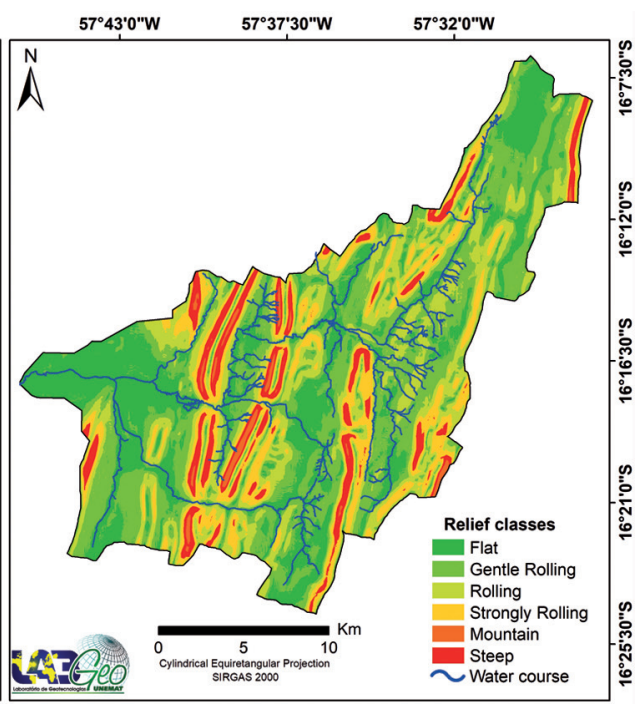

Figure 3 - Relief types identified in the Ribeirão Jacobina basin Cáceres/MT

Around 13,986 ha from the basin are destined to the preservation of vegetation, due to steep relief and rivers, being classified as $6 \mathrm{f} f$ regarding agricultural aptitude (Figure 4). The impact of inadequate land use results in the degradation of PPAs along rivers and springs at the Pantanal biome, acting negatively on the regional hydric dynamics and interfering in the inundation pulse of the floodplain (LORENZON).

The agricultural aptitude class $2(a)(b)$ occupies $26.27 \%$ of Ribeirão Jacobina basin, constituting adequate areas for agriculture and pasture. According to SILVEIRA et al. (2015), terrains subject to soil and relief limitations need the implementation of high management technology to adapt the land use to aptitude recommendations.

The agricultural aptitude class 1 (a)bc occurs on $24.5 \%$ of the basin, whose lands are considered as adequate for annual cultures and pasture. Areas with this classification are characterized by well drained soils, which allow the development of a root system as well as retention and supply of nutrients for cultures. The flat relief of this area allows the expansion of mechanization processes with the necessary technology to increase the annual cultures planted. Sakamoto et al.(2012), based on studies from the impact of the agricultural expansion in the Pantanal biome found out that the hydric dynamics (flood and drought periods) of the ecosystem mobilizes chemical elements in the soil originated from agro-toxics and fertilizers of the agriculture, suggesting the fragility of this environment under intensive human use conditions.

Livestock is the predominant land use in the basin under study (Figure 5), and in some places the native vegetation was eliminated in the PPAs. (Figure 6). Along rivers and around springs, where pastures were identified, a fast intervention is necessary, with conservationist and recovery practices, due to earlier occupation processes without planning. 


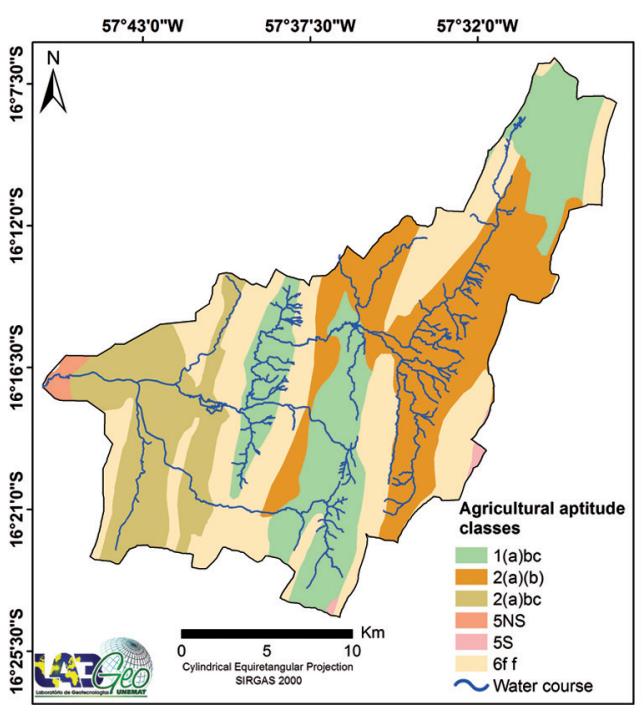

Figure 4 - Agriculture aptitude classes in the Ribeirão Jacobina basin - Cáceres/MT

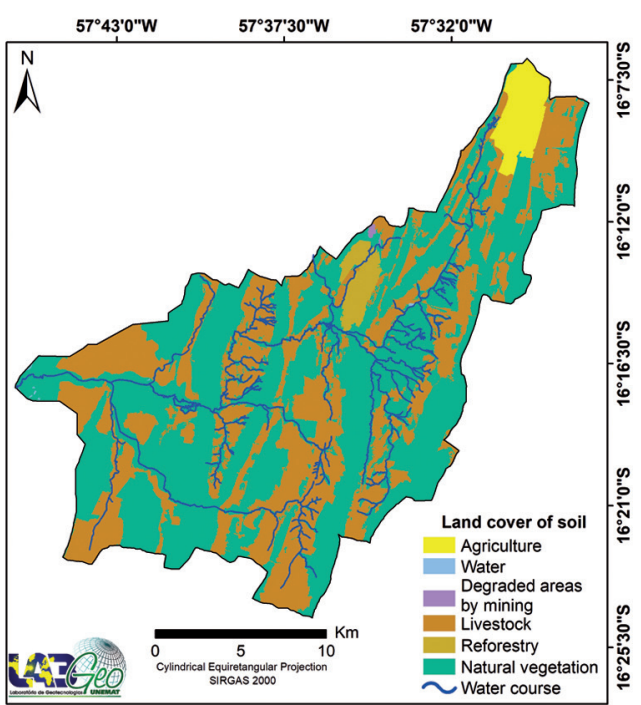

Figure 5 - Land use / land cover classes in the Ribeirão Jacobina basin - Cáceres/MT

Agriculture in the area under study is done on deep and well drained soils (Red Oxisols) and flat relief (Table 3), and there are no inadequacies regarding aptitude of soils. According to Harris et al. (2006), the increase of areas directed to agriculture in the Pantanal is restricted to the surrounding plateaus of the big floodplain at the municipalities from the Upper Paraguay basin. The results are high deforestation rates, mainly on the plateau area. Being so, there is a conversion of native in agriculture areas, which is an important vector of environmental degradation, with an important silting of sediments in rivers and springs (Figure 7). Similarly Santos et al. (2011) report that the systematic deforestation occurring on the plateau adjacent to the Pantanal generates impacts of different magnitude in this huge floodplain.

Along the Ribeirão Jacobina basin 33 ha in extension were identified for limestone mining. It is of fundamental importance to monitor the expansion of degraded areas by mining, taking into account that mineral production and the subsequent changes in the natural vegetation generate, environmental, social and economic impacts for the Cáceres municipality. According to Cardozo et al. (2016, p.101) remote sensing and GIS technologies deliver information and statistical data for "the evaluation of land use change while the mining is active. These data can be used to perform policies and directives for its management after the end of the activities", considering the need for environmental recovery of them, and possible socio-economic alternatives for the reinsertion of the area in the productive process.

A strong conflict on land use was found out in areas with Humic Cambisols on rolling relief, representing 147 ha from the basin area, presenting exotic pasture (Table 2 ), which contributes to accelerate the degradation of these soils. These results were also reported by Amaral et al. (2004), concluding that Humic Cambisols on the medium part of slopes, affecting all soil and environmental attributes, such as effective soil depth, internal drainage of the profile and surface erosion. 


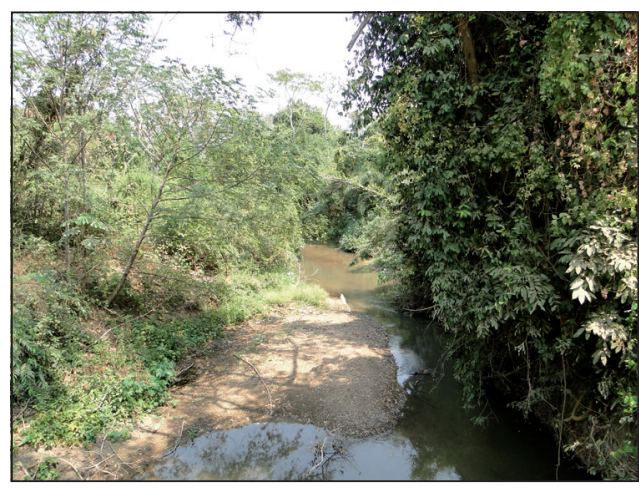

Figure 6 - Pasture areas surrounding a water body in the Ribeirão Jacobina basin in Cáceres/MT

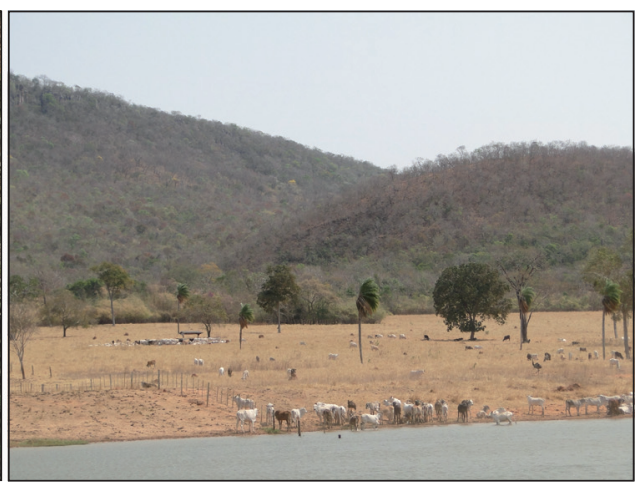

Figure 7 - Sediment accumulation in the Ribeirão Jacobina in Cáceres/MT

\section{Table 2 - Agriculture aptitude classes of soils in the Ribeirão Jacobina basin, Cáceres/MT}

\begin{tabular}{|c|c|c|c|c|c|}
\hline $\begin{array}{c}\text { Soil } \\
\text { Classes }\end{array}$ & $\begin{array}{l}\text { Relief } \\
\text { types }\end{array}$ & $\begin{array}{c}\text { Agriculture } \\
\text { aptitude Classes }\end{array}$ & $\begin{array}{l}\text { Land use / land } \\
\text { cover of soil }\end{array}$ & $\begin{array}{l}\text { Conflict } \\
\text { on use }\end{array}$ & $\begin{array}{l}\text { Area } \\
\text { (ha) }\end{array}$ \\
\hline $\begin{array}{l}\text { Humic } \\
\text { Cambisols }\end{array}$ & $\begin{array}{l}\text { Gentle } \\
\text { Rolling to } \\
\text { Rolling }\end{array}$ & $\begin{array}{l}\mathbf{5} \mathbf{S} \text { - Without } \\
\text { agriculture aptitude, } \\
\text { regular for forestry }\end{array}$ & $\begin{array}{l}\text { Livestock }(42.62 \%)+ \\
\text { Vegetation }(57.38 \%)\end{array}$ & High & 147 \\
\hline $\begin{array}{l}\text { Red-Yellow } \\
\text { Oxisols }\end{array}$ & $\begin{array}{l}\text { Flat to } \\
\text { Gentle } \\
\text { Rolling }\end{array}$ & $\begin{array}{l}\mathbf{2 ( a ) b c}-\text { Regular for } \\
\text { tillage, apt for } \\
\text { pasture; apt for } \\
\text { pasture }\end{array}$ & $\begin{array}{l}\text { Livestock }(48.63 \%)+ \\
\text { Vegetation }(51.33 \%) \\
+ \text { Water }(0.04 \%)\end{array}$ & Low & 7,444 \\
\hline $\begin{array}{l}\text { Red } \\
\text { Oxisols }\end{array}$ & $\begin{array}{l}\text { Flat to } \\
\text { gentle } \\
\text { Rolling }\end{array}$ & $\begin{array}{l}\mathbf{1}(\mathbf{a}) \mathbf{b c}-\text { Apt for } \\
\text { tillage with } \\
\text { conservationist } \\
\text { management, apt for } \\
\text { pasture }\end{array}$ & $\begin{array}{l}\text { Livestock }(56.56 \%)+ \\
\text { Vegetation }(31.46 \%) \\
+ \text { Agriculture } \\
(11.98 \%)\end{array}$ & Low & 10,912 \\
\hline $\begin{array}{l}\text { Haplic } \\
\text { Luvisols }\end{array}$ & $\begin{array}{l}\text { Gentle } \\
\text { Rolling to } \\
\text { Rolling }\end{array}$ & $\begin{array}{l}\mathbf{2 ( a ) ( b )}-\text { Regular } \\
\text { for tillage and } \\
\text { pasture }\end{array}$ & $\begin{array}{l}\text { Livestock }(32.57 \%)+ \\
\text { Vegetation }(60.87 \%) \\
+ \text { Agriculture }(0.07 \%) \\
+ \text { Degraded areas by } \\
\text { mining }(0.27 \%)+ \\
\text { Reforestation }(6.17 \%) \\
+ \text { Water }(0.07 \%)\end{array}$ & Medium & 11,595 \\
\hline $\begin{array}{l}\text { Fluvic } \\
\text { Arenosols }\end{array}$ & Flat & $\begin{array}{l}\text { 5NS - Without } \\
\text { agriculture aptitude, } \\
\text { regular for natural } \\
\text { pasture and forestry }\end{array}$ & $\begin{array}{l}\text { Vegetation }(98.28 \%) \\
+ \text { Water }(1.72 \%)\end{array}$ & Low & 391 \\
\hline $\begin{array}{l}\text { Litholic } \\
\text { Arenosols }\end{array}$ & $\begin{array}{l}\text { Rolling to } \\
\text { strongly } \\
\text { rolling }\end{array}$ & $\begin{array}{l}\text { 6f } \mathbf{f} \text { - Destined to } \\
\text { permanent } \\
\text { preservation; with } \\
\text { restrictions due to } \\
\text { agro-environmental } \\
\text { conditions }\end{array}$ & $\begin{array}{l}\text { Livestock }(18.57 \%)+ \\
\text { Vegetation }(80.48 \%) \\
+ \text { Agriculture }(0.32 \%) \\
+ \text { Reforestry }(0.63 \%)\end{array}$ & Medium & 13,986 \\
\hline
\end{tabular}


The average conflict on land use was identified in areas of Haplic Luvisols and Litholic Arenosols, representing 25,581 ha, with predominantly native vegetation (Figure 8 ). Nevertheless, there are areas destined to livestock, agriculture and mining activities under these soils. The inadequacy of land use with the soil aptitude are aggravating factors for soil degradation and reduction of the native forest. Cardoso et al. (2011) mention the negative effects from land use change in the Pantanal. Among them should be mentioned: habitat fragmentation, invasion of exotic species, pollution of aquifers, reduction of the soils quality and ecosystems degradation. In this sense, the adequacy of land use tends to promote the restauration of native areas in the basin, aiming to the reduction of these conflicts.

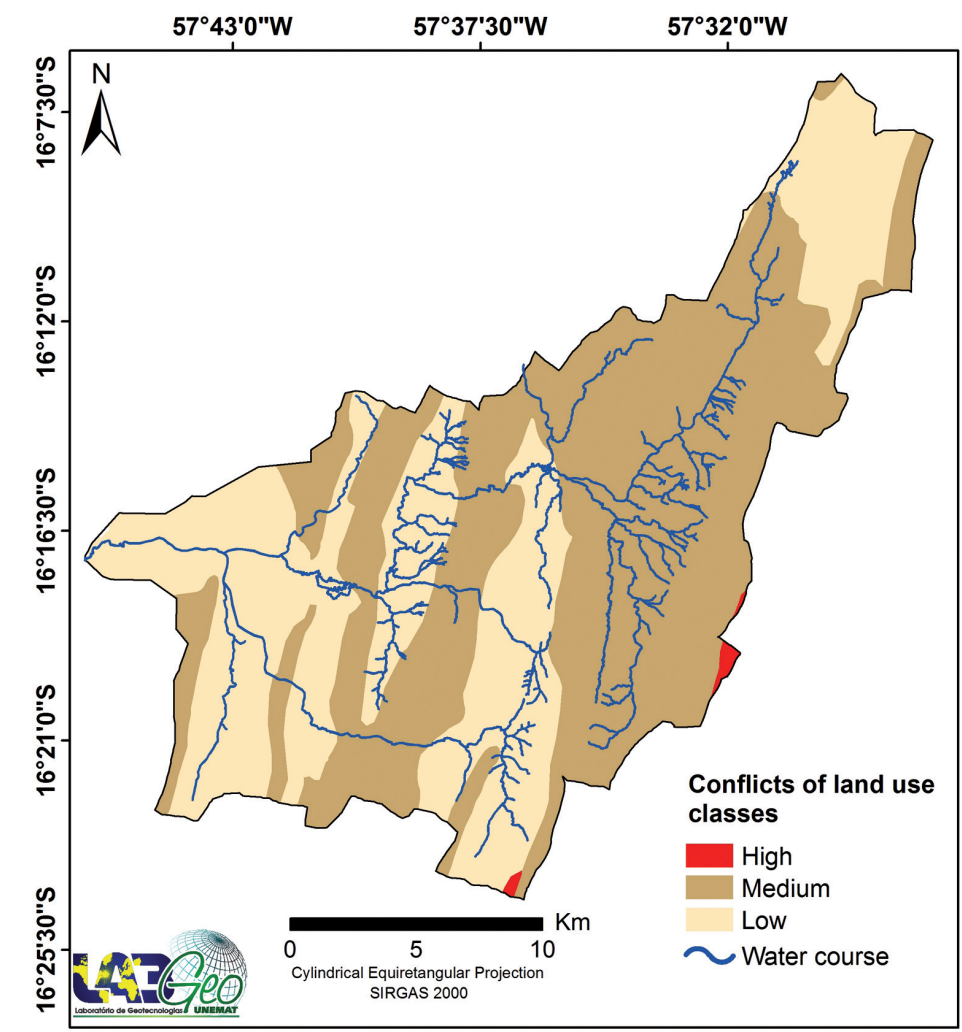

Figure 8 - Land use conflict in the Ribeirão Jacobina basin -
Cáceres/MT

The low conflict on land use was identified on places where agriculture was the dominant use on Latosols and vegetation covered the Fluvic Arenosols with an extension of 18,747 ha (Figure 8 ). The expansion of agriculture within the basin, particularly soybeans, configures the first steps of pasture elimination for the insertion of agriculture with a high technological level. According to Santos e Sano (2015), changes occurring on the profile of livestock production, demand capital and technological investments in the field, with modern agriculture, and consequently also with an intensive use of chemical inputs. The phyto-patologic management of pests and diseases at soybean 
plantations is made by an excessive application of pesticides, resulting in the contamination, by toxic elements, of rivers and soils. In this context, Calheiros et al., (2010), analyzing water samples in monoculture areas, especially soybeans at the Upper Paraguay basin (UPB) verified the presence of residues of pesticides in the water, considering the sub-lethal effects, which non-target organisms on the long run, such as the aquatic flora, including algae, compromising the base of the food chain in the Pantanal.

It was verified that 1,802 ha from the basin correspond to protected areas of water resources - PPAs (Figure 9) - and that from this amount 459 ha are destined to livestock activities and 23 ha for reforestation. There are conflicts, because the present legislation does not allow the use of these spaces (Table 3).

\section{Table 3 - Land use classes and vegetation of PPAs of rivers and springs in the basin of Ribeirão Jacobina, Cáceres / MT}

\begin{tabular}{lccc}
\hline Land use classes and vegetation & $\begin{array}{l}\text { Area } \\
\text { (ha) }\end{array}$ & \% & Conflict \\
\hline Livestock & 459 & 25.47 & Existing \\
Reforestation & 23 & 1.28 & Existing \\
Vegetation & 1320 & 73.25 & Absent \\
\hline Total & $\mathbf{1 8 0 2}$ & $\mathbf{1 0 0}$ & \\
\hline
\end{tabular}

Pessoa et al, (2013) verified that in the Medium Rio Paraguay basin, the expansion of the planted pastures in the surroundings of the water courses increased constantly till 2011, deflagrating the need to recover the lowland forests. One must consider that a lowland forest acts in the reduction of the speed from the sediment flow, acting as a filter. In those areas with crossing of animals related to pastures, there is an increase of sediment, that are transported to the rivers. PAIVA et al. (2014), studying land use conflicts in the PPAs of Ribeirão Jacobina basin with LANDSAT 8 images from 2013, verified the presence of conflicts, mainly due to livestock activities within the PPAs, corroborating with the results from this work. Considering the importance of this basin for the maintenance of the inundation pulse from the Pantanal, recovery works are needed at the degraded PPAs, as well as control actions to identify the inadequacies from governmental side, to avoid that the owners use the land in disagreement with the legislation.

The use of reforestation for the recovery of PPAs is ruled by Resolution No. 429 (BRASIL, 2011), which considers that reforestation must be made with planted native species, conduction of natural regeneration and, under some circumstances, recovery with exotic species is allowed, considering that article 66 of the Forest Code (BRASIL, 2012) which establishes that plantations of exotic species must be combined with regional occurring native species and that the area of exotic species cannot exceed $50 \%$ of the total area to be recovered.

Nevertheless the area identified as reforestation within the basin under study refers to na área with Teca (Tectona Grandis) plantation, which constitutes a conflict when it is localized in a PPA surrounding hydric resources. Several authors report on the advantages of forestry over agriculture and livestock for water quality and conservation but, when compared to the native vegetation, its performance is lower (FREITAS et al., 2013; BUENO et al., 2005), emphasizing the importance of revegetation with native species in PPAs of rivers and springs. Kreitlow et al., (2014) identified apt and inapt areas for Teca plantations in Cáceres, Mato Grosso State, corroborating with 
this study when classifying those areas of the municipality as inapt for Teca plantations, considering the preservation of this hydrographic net for flooding of land within the Pantanal.

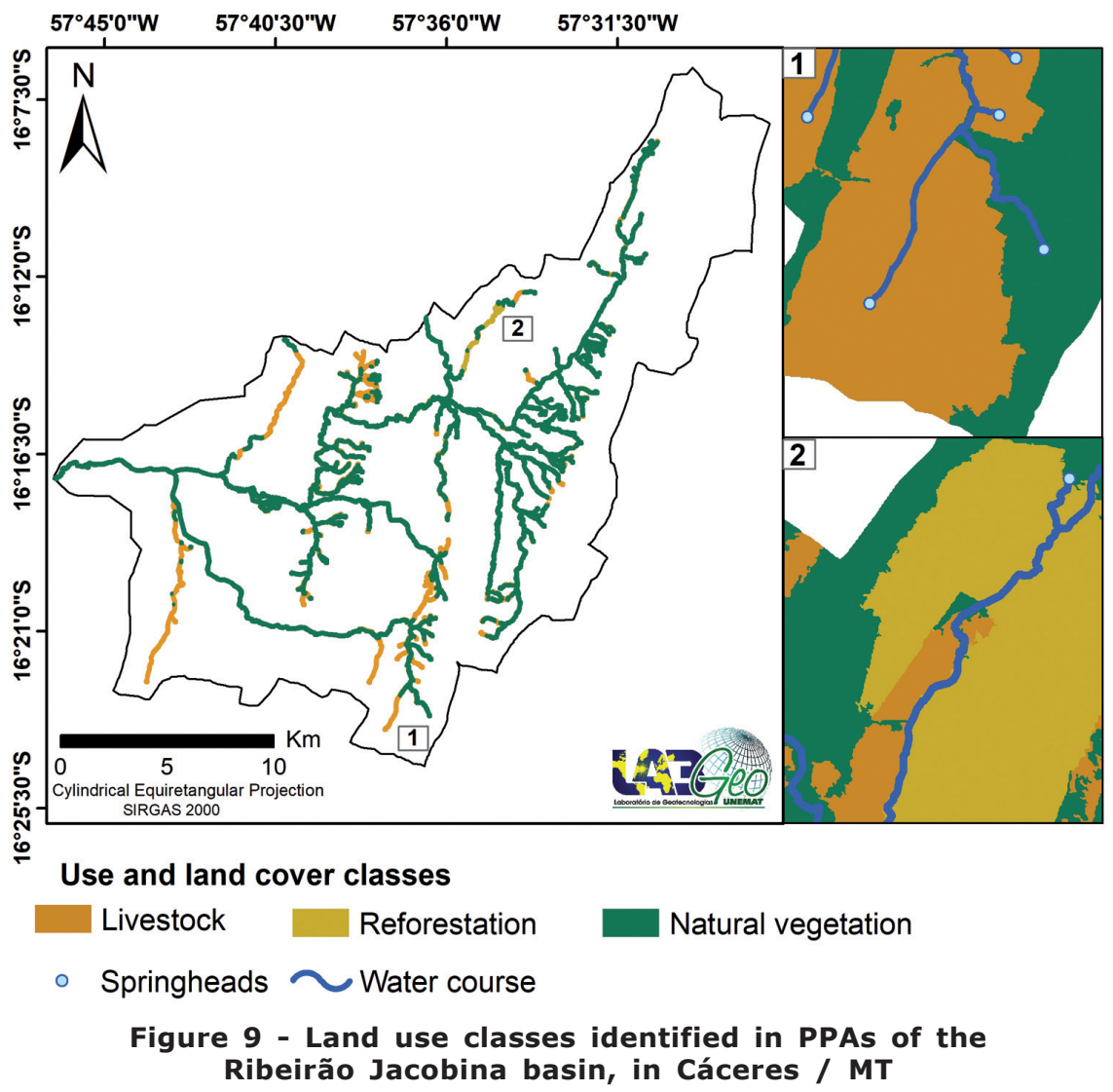

The association of factors such as soils, declivity, land use/land cover proposed by Ramalho Filho e Beek (1995), allowed the verification of the need of planning policies to sponsor a territorial occupation in accordance with the support capacity of the environment in the Ribeirão Jacobina basin, and the geo-technologies are extremely important tools for the fast identification and low costs of areas with conflicting uses.

\section{CONCLUSIONS}

In the Ribeirão Jacobina basin a medium conflict class of land use predominates, due to the predominant livestock activities within environmentally sensitive areas. There is a need to adequate land use to the agricultural aptitude. 
The geo-technologies allowed the visualization of soybean expansion in the basin. Because it is an annual culture, it is not indicated for soils with low aptitude, mainly Neossolos, which have an effectively low depth.

Monitoring of the conservation status from PPAs in the Ribeirão Jacobina basin is necessary to keep the quality and availability of water, as well as for the indispensable recovery and control activities at the degraded PPAs.

\section{ACKNOWLEDGMENTS}

The authors thank the FAPEMAT (Mato Grosso State Foundation for Research) for their awarding of scholarship grants. We used information derived from Project Modeling environmental indicators for the definition of priority and strategic areas for the recovery of degraded areas in SW Mato Grosso State. This project is connected to the subnet of social, environmental and technological studies for the production system of SW Mato Grosso (REDE ASA), funded in the frame of edict MCT/CNPq/FNDCT/FAPs/ MEC/CAPES/PRO-CENTRO-OESTE No 031/2010. Data from this project contributed to the execution of this study.

\section{REFERENCES}

BRASIL. Empresa Brasileira de Brasileira de Pesquisa Agropecuária. Centro Nacional de Pesquisas de solos. Sistema Brasileiro de Classificação de Solos. 3 ed. Rio de Janeiro: Embrapa, 2013. 306p.

BRASIL. Instituto Brasileiro de Geografia e Estatística. Manual técnico de pedologia. 2 ed. Rio de Janeiro: IBGE, 2007. p. 189-191.

BRASIL. Instituto Brasileiro de Geografia e Estatística. Manual técnico de uso da terra. 3 ed. Rio de Janeiro: IBGE, 2013. 171 p.

BRASIL. Lei n.o 12. 651, de 25 de maio de 2012. Dispõe sobre a proteção da vegetação nativa. Diário Oficial [da] República Federativa do Brasil, Brasília, DF, 25 maio de 2012. Disponível na biblioteca digital URLib <<http://www.planalto.gov.br/ ccivil_03/ _Ato2011-2014/2012/Lei/L12651.htm>> Acesso em: 30 jun. 2016.

BRASIL. Ministério do Meio Ambiente. Conselho Nacional do Meio Ambiente. Resolução CONAMA $n^{\circ} 429$ de 28 de fevereiro de 2011. Dispõe sobre a metodologia de recuperação das Áreas de Preservação Permanente - APPs. Disponível em: URLib: <http://www.mma.gov.br/port/conama/legiabre.cfm?codlegi=644>. Acesso em: 01 fev. 2017.

BUENO, L. F.; GALBIATTI, J. A.; BORGES, M. J. Monitoramento de variáveis de qualidade da água do horto Ouro Verde - Conchal - SP. Engenharia Agrícola, v. 25, n. 3, p. 742-748, 2005.

CARDOSO, E. L.; SILVA, M. L. N.; CURI, N.; FERREIRA, M. M.; FREITAS, D. A. F. Qualidade química e física do solo sob vegetação arbórea nativa e pastagens no Pantanal Sul-Mato-Grossense. Revista Brasileira de Ciência do Solo, v. 35, n. 2, p. 613-622, 2011. 
CARDOZO, F. A. C.; PIMENTA, M. M.; RIBEIRO, R. R. Sensoriamento remoto aplicado na detecção de áreas degradadas pela mineração no Sul do Brasil entre 1985 - 2011. Tecno-Lógica, v. 20, n. 2, p. 97-102, 2016.

CALHEIROS, D. F.; FERRACINI, V. L.; QUEIROZ, S. C. N.; Contaminação por agrotóxicos nas águas da Bacia do Alto Paraguai. In: SEMINÁRIO DE AGROECOLOGIA DE MATO GROSSO DO SUL, 18., 2010, Corumbá. Anais...Corumbá: Embrapa Pantanal, 2010. p. 1-5. Disponível em: <http://ainfo.cnptia.embrapa.br/digital/bitstream/item/25125/ 1/sp17344.pdf>. Acesso em: 29 jun. 2016.

CÂMARA, G.; SOUZA, R. C. M.; FREITAS, U. M.; GARRIDO, J. SPRING: Integrating remote sensing and GIS by objectoriented data modeling. Computers \& Graphics, v. 20, n. 3, p. $395-403,1996$.

CHAUD, T. A.; OlIVEIRA, A. S.; SANTOS, S. K. F.; FARIA, A. A.; CAMACHO, H. A. M.; MOREIRA, J. A.; BRITO, R. A. M. Aplicabilidade do Código Florestal na microbacia mariana do município de Alta Floresta, Estado de Mato Grosso. Interdisciplinar: Revista Eletrônica da UNIVAR, n. 14, v. 2, p. 93 - 102, 2015.

CHOPRA, R.; DHIMAN, R. D.; SHARMA, P. K. Morphometric analysis of sub-watersheds in Gurdaspur district, Punjab using remote sensing and GIS techniques. Journal of the Indian Society of Remote Sensing, v. 33, n. 4, p. 531 - 539, 2005.

CUTRIM, A. O.; CAMPOS, J. E. G. Avaliação da vulnerabilidade e perigo à contaminação do aqüífero furnas na cidade de Rondonópolis (MT) com aplicação dos métodos God e Posh. Geociências, v. 29, n. 3, p. 401-411, 2010.

ESRI. Environmental Systems Research Institute. ArcGIS Professional GIS for the desktop, versão 10.5 advence, CA., 2017.

FERRARI, J. L.; SANTOS, A. R. S.; GARCIA, R. F.; AMARAL, A. A.; PEREIRA, L. R. Análise de Conflito de Uso e Cobertura da Terra em Áreas de Preservação Permanente do Ifes - Campus de Alegre, Município de Alegre, Espírito Santo. Floresta e Ambiente, v. 22, n. 3, p. 307-321, 2015.

FORNELOS, L. F.; NEVES, S. M. A. S. Uso de modelos digitais de elevação (MDE) gerados a partir de imagens de radar interferométricos (SRTM) na estimativa de perdas de solo. Revista Brasileira de Cartografia, v. 1, n. 59, p. 25-33, 2007.

FREITAS, E. P.; MORAES, J. F. L.; PECHE FILHO, A.; STORINO, M. Indicadores ambientais para áreas de preservação permanente. Revista Brasileira de Engenharia Agrícola e Ambiental, v. 17, n. 4, p. 443-449, 2013.

GOMES, N. M.; FARIA, M. A.; SILVA, A. M.; MELLO, C. R.; VIOLA, M. R. Variabilidade espacial de atributos físicos do solo associados ao uso e ocupação da paisagem.

Revista Brasileira de Engenharia Agrícola e Ambiental, v. 11, n. 4, p. 427-435, 2007.

HARRIS, M. B.; ARCÂNGELO, C.; PINTO, E. C. T.; CAMARGO, G.; RAMOS NETO, M. B.; SANDRO MENEZES SILVA, S. M. Estimativa da perda de cobertura vegetal original na Bacia do Alto Paraguai e Pantanal brasileiro: ameaças e perspectivas. Natureza \& Conservação, v. 4, n. 2, p. 50-66, 2006.

KREITLOW, J. P.; NEVES, S. M. A. S.; NEVES, R. J.; SERAFIM, M. E. Avaliação geoambiental das terras do município brasileiro de Cáceres para o cultivo da Teca. Revista Ra'e Ga, v. 31, n. 4, p. 53-68, 2014.

LEMOS, R. C.; SANTOS, R. D. Manual de descrição e coleta de solo no campo. 4 ed. Viçosa/MG: Sociedade Brasileira de Ciência do Solo, 2002. 83 p. 
LEPSCH, I. F.; ESPINDOLA, C. R.; VISCHI FILHO, O. J.; HERNANI, L. C. Manual para levantamento utilitário e classificação de terras no sistema de capacidade de uso. Campinas/SP: Sociedade Brasileira de Ciência do Solo, 2015. 170 p.

LORENZON, T. H.; PAIVA, S. L. P.; NEVES, S. M. A. S.; NEVES, R. J.; NUNES, E. S. Analysis of the conservation state from the permanent protection areas at the springheads and of the water from Cabaçal river drainage basin, Mato Grosso state, Brazil. Geografia, Rio Claro, v. 40, número especial, p. 145-161, 2015.

MARQUES, A. F. S. M.; MARTINS JÚNIOR, P. P.; VASCONCELOS, V. V.; NOVAES, L. A. D’A. Proposição Metodológica para a Cartografia de Solos e Aptidão Agrícola: Estudo de Caso para a Bacia do Rio Paracatu. Revista Brasileira de Geografia Física, v. 1, n. 1, p. 01-17, 2012.

MATO GROSSO (Estado). Secretaria de Estado de Planejamento e Coordenação Geral. MOREIRA, M. L. C.; VASCONCELOS, T. N. N. (Org.). Mato Grosso: solos e paisagem. Cuiabá: SEPLAN, 2007. 272 p.

MATO GROSSO (Estado). Secretaria de Estado de Planejamento e Coordenação Geral. Plano de Longo Prazo de Mato Grosso: macro-objetivos, metas globais, eixos estratégicos e linhas estruturantes. In: PRADO, J. G. B.; BERTCHIELI, R.; OLIVEIRA, L. G. (Orgs). Plano de Longo Prazo de Mato Grosso. Cuiabá/MT: Central de Texto, vol. IV, 2012. 108 p. Disponível em: <<http://www.seplan.mt.gov.br/mt20/mt20.htm >> Acesso em: 30 fev. 2016

MIZIARA, F. Condições estruturais e opção individual na formulação o conceito de "Fronteira Agrícola". In: SILVA, L. S. D. (Org.). Relações cidade-campo: fronteiras. Goiânia: Editora UFG, 2000. p. 273 - 373.

NEVES, S. M. A. S.; NUNES, M. C. M.; NEVES, R. J. Caracterização das condições climáticas de Cáceres/MT Brasil, no período de 1971 a 2009: subsídios às atividades agropecuárias e turísticas municipais. Boletim Goiano de Geografia, v. 31, n. 2, p. 55-68, 2011.

NUNES, M. C. M.; CASSOL, E. A. Estimativa da erodibilidade em entressulcos de Latossolos do Rio Grande do Sul. Revista Brasileira de Ciência do Solo, v. 32, número especial, p. 2839-2845, 2008.

PAivA, S. L. P.; KReITloW, J. P.; NEVES, S. M. A. S.; NeVES, R. J.; MUNIZ, C. C. Sistemas de Informação Geográfica e Sensoriamento Remoto aplicado na análise de conflito de uso da terra na Bacia Ribeirão Jacobina-Pantanal Mato-grossense. In: SIMPÓSIO DE GEOTECNOLOGIAS NO PANTANAL, 5., 2014, Campo Grande. Anais... Campinas: Embrapa Informática Agropecuária/INPE, 2014, p. 966 -973. Disponível em <https://www.geopantanal.cnptia.embrapa.br/2014/cd/p153.pdf>. Acesso em: 29 jun. 2016.

PEREIRA, L. C.; LOMBARDI NETO, F. Avaliação da aptidão agrícola das terras: proposta metodológica. Jaguariúna: Embrapa Meio Ambiente, 2004, 36 p.

PESSOA, S. P. M.; GALVANin, E. A. S.; KREITLOW, J. P.; NEVES, S. M. A. S.; NUNES, J. R. S.; ZAGO, B. W. Análise espaço-temporal da cobertura vegetal e uso da terra na Interbacia do rio Paraguai Médio-MT, Brasil. Revista Árvore, v. 37, n. 1, p. 119-128, 2013.

PINTO, L. V. A.; FERREIRA, E.; BOTELHO, S. A.; DAVIDE, A. C. caracterização física da bacia hidrográfica do Ribeirão Santa Cruz, Lavras, MG e uso conflitante da terra em suas Áreas de Preservação Permanente. Cerne, v. 11, n. 1, p. 49-60, 2005.

RAMALHO FILHO, A.; BEEK, K. J. Sistema de avaliação da aptidão agrícola das terras. 3 ed. Rio de Janeiro: Embrapa/ CNPS, 1995. 65 p. 
SAKAMOTO, A. Y.; BACANI, V. M.; GRADELLA, F. S.; FERREIRA, C. C.; DECCO, H. F. Desmatamento e alterações ambientais no Pantanal da Nhecolândia, MS, Brasil. Revista Geonorte, Edição Especial, v. 3, n. 4, p. 827-839, 2012.

SANTOS, C. A. P.; SANO, E. E. Formação da frente de expansão, frente pioneira e fronteira agrícola no oeste da Bahia. Boletim de Geografia, v. 33, n. 3, p. 68-83, 2015.

SANTOS, G. O.; HERNANDEZ, F. B. T.; DANTAS, G. F.; SANTOS, D. J. O. Mapeamento e caracterização das Áreas de Preservação Permanentes no Córrego do Ipê, Ilha Solteira, SP. Ciência \& Tecnologia, v. 7, n. 1, p. 28-38, 2015.

SILVA, J. S. V.; ABDON, M. M.; NEVES, S. M. A. S; MORAES. J. A. Evolution of deforestation in the brazilian Pantanal and surroundings in the timeframe $1976-2008$. Geografia, Rio Claro, v. 36, Número Especial, p. 35-55, 2011.

SANTOS, M. A.; BARBIERI, A. F.; CARVALHO, J. A. M.; MACHADO, C. J. o Cerrado brasileiro: notas para estudo. Belo Horizonte: UFMG/Cedeplar, n. 387, 2010. 15 p.

SILVA, E. B.; NOGUEIRA, R. E.; UBERTI, A. A. A. Avaliação da aptidão agrícola das terras como subsídio ao assentamento de famílias rurais, utilizando sistemas de informações geográficas. Revista Brasileira de Ciência do Solo, v. 34, n. 2, p. 1977-1990, 2010.

SILVA, J. R. P.; CARMO, E. M. Estudo dos Conflitos Ambientais no Assentamento e App's do Igarapé do Bruno - Apiacás-MT. In: SIMPÓSIO BRASILEIRO DE CIÊNCIAS GEODÉSICAS E TECNOLOGIAS DA GEOINFORMAÇÃO, 3., 2010, Recife. Anais...Recife: Pós-graduação de ciências geodésicas e tecnologias da geoinformação, Universidade Federal de Pernambuco, 2010, p. 001-009. Disponível em: <https://www.ufpe.br/ cgtg/SIMGEOIII/index1.htm>. Acesso em: 29 jun. 2016.

SILVA, J. S. V.; ABDON, M. M. Delimitação do Pantanal brasileiro e suas sub-regiões. Pesquisa Agropecuária Brasileira, v. 33, n. Especial, p. 1703-1712, 1998.

SILVEIRA, G. R. P.; CAMPOS, S.; GONÇALVES, A. K.; BARROS, Z. X.; POLLO, R. A. Geoprocessamento aplicado na espacialização da capacidade de uso do solo em uma área de importância agrícola. Energia Agrícola, v. 30, n. 4, p. 363-371, 2015. 